
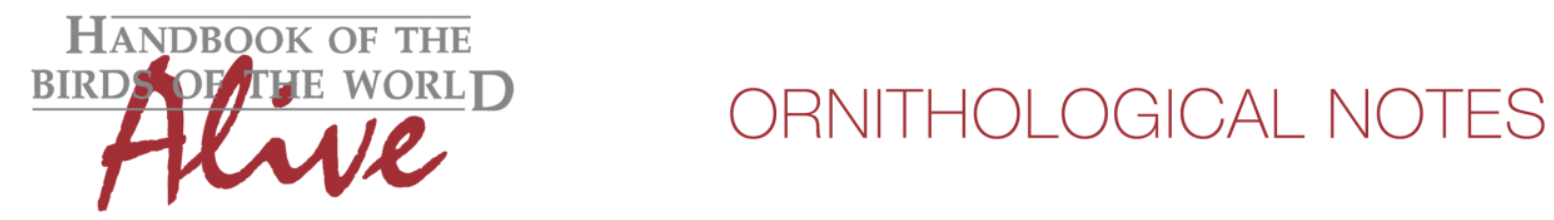

\title{
Notes on the vocalizations of Arafura Fantail (Rhipidura dryas)
}

Peter Boesman

In the following we briefly analyze and compare voice of the different races of Arafura Fantail (Rhipidura dryas). We also try to quantify the extent of any vocal differences using the criteria proposed by Tobias et al. (2010), as a support for taxonomic review. We have made use of sound recordings available on-line from Xeno Canto (XC).

Three groups are mentioned in HBW (Boles 2016):

1. "squamata group" (also including henrici, which sometimes merged with squamata) in $\mathrm{S}$ Moluccas and W Papuan Is

2. "elegantula group" (with reichenowi and hamadryas) in E Lesser Sundas

3. "nominate group" (including streptophora, semicollaris, sumbensis, celebensis and mimosae) in S New Guinea, C Lesser Sundas and Australia

Vocally these three groups are not readily recognized (from a quick look at sonograms). It would seem that recordings from Alor, Timor-Leste, Wetar and Pantar (which basically coincides with the race semicollaris) have the most distinctive song, consisting of short, fast rising series of 3 notes repeated a few times:
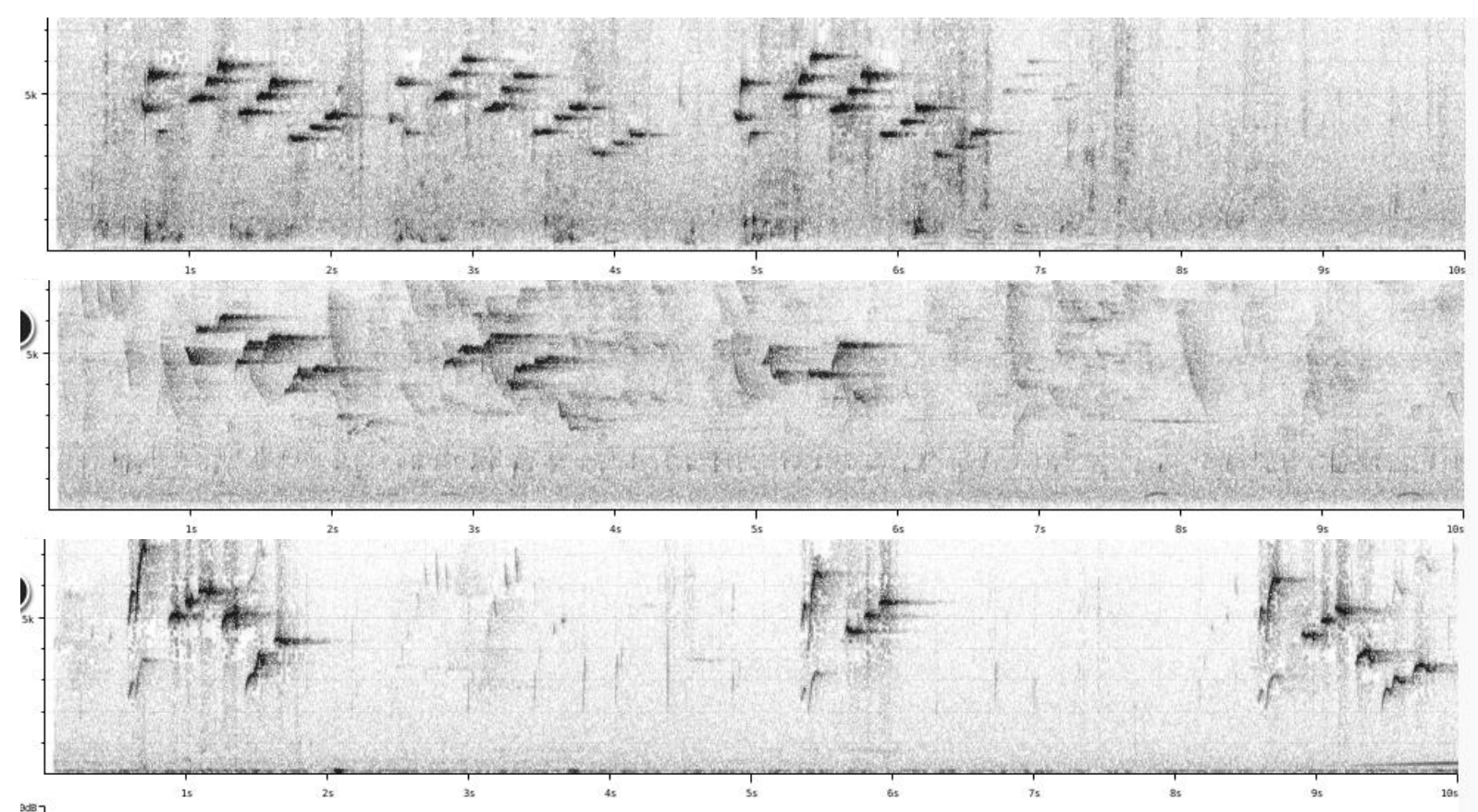


\section{HANDBOOK OF THE \\ BIRD S PF/THE WORLD}

\section{ORNITHOLOGICAL NOTES}

Other races in western Lesser Sundas have the more typical song shared with eastern races: Some examples:

Sumba (sumbensis) $=$ group 3

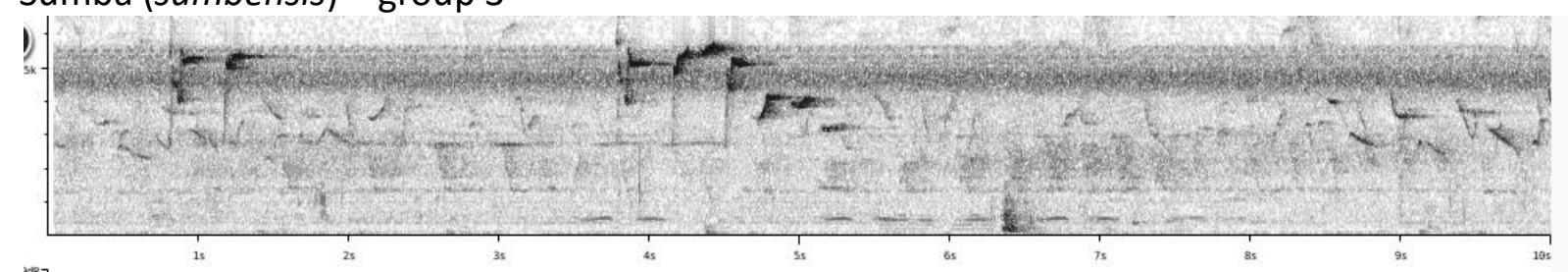

Flores Sea $=$ group 3

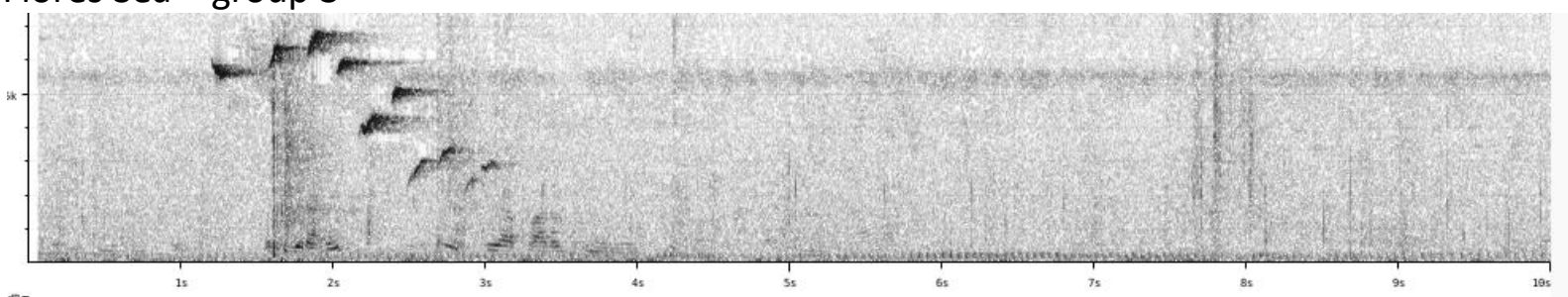

Damar island (elegantula) = group 2

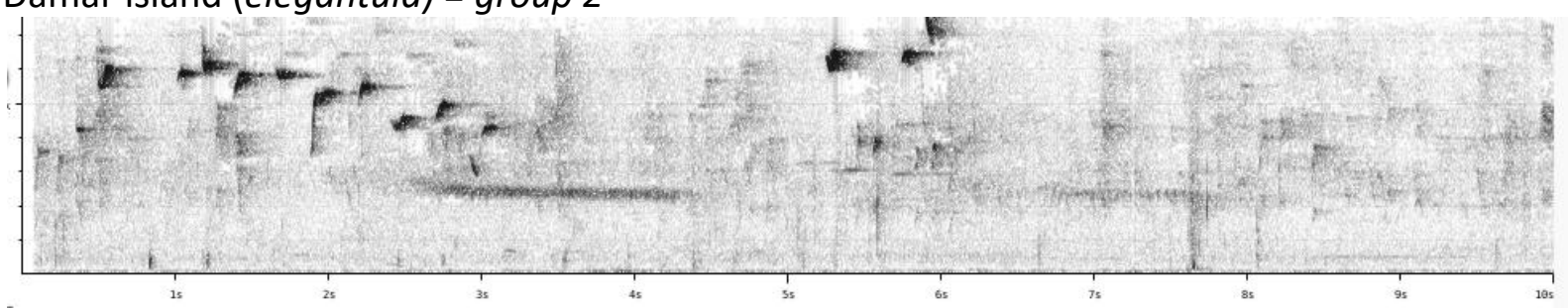

Maluku (squamata) $=$ group 1

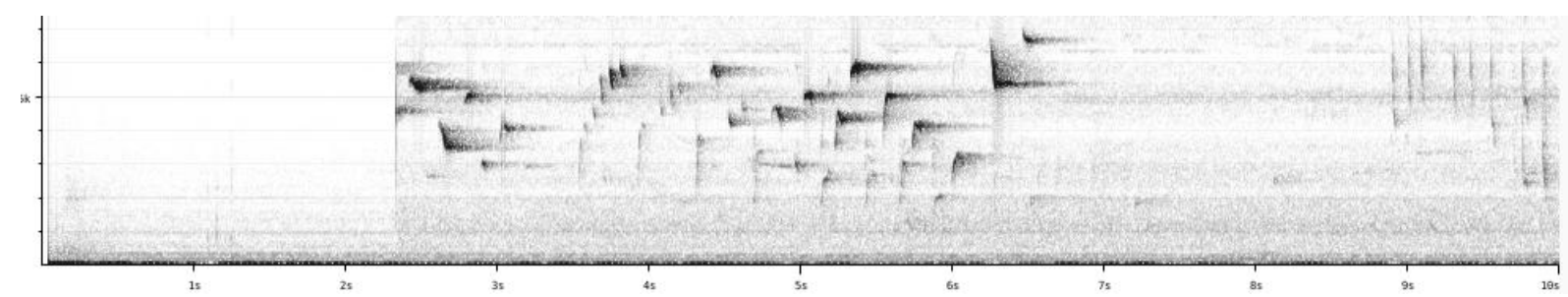

$\mathrm{N}$ Australia (dryas) $=$ group 3

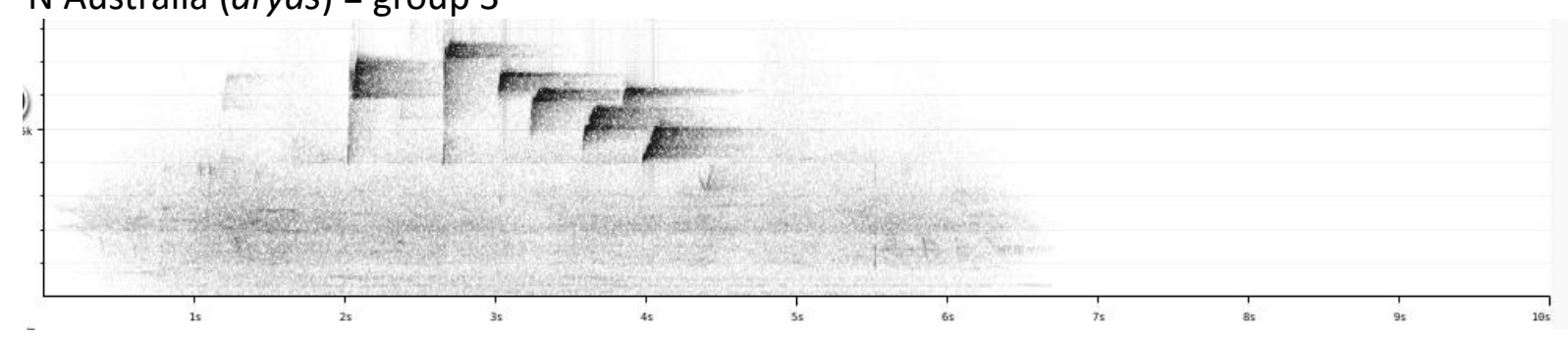

It is thus quite striking that semicollaris, about in the middle of the distribution of the nominate group, is vocally so different. Of all other races, based on the few recordings available, dryas seems to be the most deviating (slightly higher-pitched and more emphatic). Which actually indicates that all vocal variation is within group 3 (nominate group).

It would thus seem that the proposed grouping based on morphological (?) characteristics, is not supported by a similar differentiation vocally. From this short analysis, we can at most conclude that race semicollaris (spread over several islands) is vocally the most distinctive. 
This note was finalized on 15th January 2016, using sound recordings available on-line at that moment. We would like to thank in particular the sound recordists who placed their recordings for this species on XC: Marc Anderson, Mike Catsis, Frank Lambert, Mike Nelson, Colin Trainor and Bas van Balen.

\section{References}

Boles, W. (2016). Arafura Fantail (Rhipidura dryas). In: del Hoyo, J., Elliott, A., Sargatal, J., Christie, D.A. \& de Juana, E. (eds.). Handbook of the Birds of the World Alive. Lynx Edicions, Barcelona. (retrieved from http://www.hbw.com/node/59163 on 15 January 2016).

Tobias, J.A., Seddon, N., Spottiswoode, C.N., Pilgrim, J.D., Fishpool, L.D.C. \& Collar, N.J. (2010). Quantitative criteria for species delimitation. Ibis 152(4): 724-746.

\section{Recommended citation}

Boesman, P. (2016). Notes on the vocalizations of Arafura Fantail (Rhipidura dryas). HBW Alive Ornithological Note 189. In: Handbook of the Birds of the World Alive. Lynx Edicions, Barcelona. (retrieved from http://www.hbw.com/node/932130 on 26 August 2016). 